\section{Henryk Witczyk}

Instytut Nauk Biblijnych KUL Jana Pawła II henwit@kul.pl

ORCID: 0000-0003-4451-0697

DOI: http://dx.doi.org/10.12775/BPTh.2018.009
Biblica

et

Patristica

Thoruniensia

11 (2018) 2: 177-195

ISSN (print) 1689-5150

ISSN (online) 2450-7059

\title{
Wielowymiarowa re-kreacja postaci literackich
}

\section{Multidimensional re-creation of literary characters}

Streszczenie. Każdy czytelnik narracji biblijnych znajduje się w sferze oddziaływania autora/narratora i tekstu. Jedną z ważniejszych form tego oddziaływania są postaci literackie. Wnikliwe, wszechstronne i wyczerpujące re-kreowanie postaci opowiadania sprawia, że w pewnym momencie czytelnik odkrywa w swej świadomości jej obecność; zaczyna być ona postacią żywą i prowadzącą z nim intensywny dialog, oddziałującą na jego zachowanie, sposób myślenia i działania. W celu oddziaływania na czytelnika przez postać literacką autor/narrator ma do wykorzystania kilka modeli: postać kluczową dla przebiegu wątku narracji; postać przemienioną w toku fabuły, postać mającą wyjątkową specyfikę czy wreszcie postać silnie oddziałującą na inne postaci narracji jako protagonista lub antagonista.

Wielkie postaci literackie, stworzone przez autorów piszących z natchnieniem, a w szczególności przez autorów tworzących pod natchnieniem Ducha Bożego, spełniają cel (realizują strategię narracyjną), który postawił sobie i im autor/narrator: kształtują idealnego czytelnika nie tylko w pierwszym pokoleniu adresatów dzieła literackiego, ale przez wieki, i to pomimo zmieniających się okoliczności, uwarunkowań kulturowych czy środowiska ich życia. Czytelnik natomiast, otwierając się na oddziaływanie postaci literackiej, ma szansę odnieść podwójną korzyść z aktu lektury: po pierwsze, może głębiej wejść w świat opowiadania, aby lepiej zrozumieć złożoność prezentowanego problemu egzystencjalnego (najczęściej ponadczasowego) i całego splotu działań potrzebnych do jego rozwiązania; po drugie, może lepiej zrozumieć siebie, sens swego życia, podejmowanych zmagań, doświadczanych przeżyć bądź lepiej poznać własne szczęście, jakie płynie z unikania zagrożeń i czynników destrukcyjnie ujawniających się w postaciach negatywnych, złych moralnie i duchowo.

\footnotetext{
Abstract. In conclusion, it should be stated that every reader is influenced by the spheres of the author, narrator and text. One of the most important kinds of influence are literary characters. An insightful, comprehensive and exhaustive re-creation of the character in telling the story makes the reader discover at some point its presence in his consciousness. It becomes a living character and leads an intense dialogue with the reader, affecting his behavior, way of thinking and acting. In order to influence the reader through a literary character, the author or narrator has several available models:
} 
a key figure for the narrative motif; a character who changes in the course of the story, a character having a unique specificity or, finally, a character strongly influencing other forms of narrative as a protagonist or antagonist.

Great literary characters, created by authors writing with inspiration, and particularly by authors who are inspired by the Spirit of God, fulfill their goal (they implement a narrative strategy) that the author or narrator has set for himself and the reader. They shape the ideal reader not only in the first generation of recipients of the literary work, but for future centuries, despite changing circumstances, cultural conditions and their living environment. On the other hand, the reader, while opening himself up to the influence of the literary form, has the chance to benefit twice from the act of reading. First, he can go deeper into the world of storytelling to better understand the complexity of the existential problem (most often over time) and the whole series of actions needed to solve the problem. Second, we can better understand ourselves, the meaning of our life, the struggles we are undertaking, our experiences or better accept our joy, which flows from avoiding threats and destructive factors that appear in negative characters that are morally and spiritually evil.

Słowa kluczowe: narracja; postaci literackie; modele re-kreacji postaci literackich.

Keywords: narrative; literary character; models of re-creation of literary characters.

\section{Specyfika postaci w narracjach biblijnych}

$\mathrm{W}$ sposób szczególny narracje biblijne wyrastają z historii i kultury ludu Przymierza, Jezusa i Kościoła apostolskiego. Występujące w nich postaci nie są wytworami fantazji, statycznymi i niezmiennymi personifikacjami poszczególnych rodzajów działań lub cech charakterów, „typami” aktywności, niezmiennymi w swym działaniu od początku do końca dzieła literackiego. A motywy ich działania nie są do końca przejrzyste, niezmienne, przez co ich zachowanie w kolejnych sytuacjach nie jest łatwo przewidywalne ${ }^{1}$.

1 W ostatnich latach ukazało się kilka ważnych, wręcz klasycznych opracowań dotyczących specyfiki postaci w narracjach biblijnych. Płynące z nich najważniejsze wnioski zostały ujęte w sposób maksymalnie syntetyczny w kilku podpunktach. Do studiów tych zaliczyć należy następujące publikacje: J.L. Ska, „Our Fathers have Told Us”, s. 83-94; M. Sternberg, The Poetics of Biblical Narrative, s. 475-481; S. Bar Efrat, Narrative Art in the Bible, s. 47-92; R. Alter, L'arte Della narratica biblica. 


\subsection{Rozwój pod ręką Boga}

Postaci biblijne są pojedynczymi, nieustannie rozwijającymi się, indywidualnymi, nie do końca i nie we wszystkim zrozumiałymi osobami. Przeżywane przez nich wydarzenia życiowe oraz wymagający heroicznej wiary i poświęcenia Bóg, wciąż je formują, kształtują, doskonalą. Nie zatracając swej tożsamości, osiągają w starości wielkość, której na początku ich życia nie można było nawet przewidywać (np. młody Jakub wyłudzający błogosławieństwo i stary Jakub rozdzierany przez ból z powodu utraty Józefa; młody Dawid prześladowany i stary król otoczony intrygantami).

\subsection{Motywacja i cele działania wynikają z życia w więzi z Bogiem}

Każda z postaci biblijnych - na skutek osobistych przeżyć i z racji wieku - ma jakiś bardzo indywidualny rys („charakter”). Narracje biblijne chętnie ukazują, w jaki sposób postać dochodzi do podjęcia określonego działania. W ten sposób narracje biblijne w naturalny sposób wciągają czytelnika w analizowanie motywacji działań poszczególnych postaci i w refleksję, na ile wybrane przez te postaci działania są adekwatne do motywacji, zamierzonych celów, do życia w więzi z Bogiem.

\subsection{Manifestacja wielkości Boga (Jego woli) w ludzkiej małości}

Postaci z opowiadań biblijnych są bardzo bliskie realistycznej wizji człowieka, gdyż odzwierciedlają pełną sprzeczności i napięć złożoność ludzkiej osoby, jej działań i życia.

Tę złożoność ludzkiego życia i działania widać w opowiadaniach Księgi Rodzaju: w konfliktowy styl życia rodzinnego wpisuje się jednak tajemnicza siła błogosławieństwa i wybraństwa.

Podobnie w Nowym Testamencie wiele postaci przypomina wahadło: od odważnego wyznania wiary, przez wahania, aż do cierpienia w więzieniu, z perspektywą męczeńskiej śmierci. W swej małości i wielkości postaci biblijne są bardzo bliskie każdemu, zwykłemu człowiekowi. Taka właśnie postać literacka - nieuosabiająca wyjątkowych cech lub działań - może znacznie mocniej oddziaływać na czytelnika niż postać monumentalna, doskonałe uosobienie jakiejś cnoty lub wady bądź umiejętności działania.

Jak trafnie pisze E. Auerbach: „Bohaterowie biblijni z jednej strony pełnią wolę Bożą, ale z drugiej mogą błądzić, mogą popaść w niełaskę lub zostać 
upokorzeni; co więcej, pośród nieszczęść i upokorzeń zarysowuje się - w ich działaniach i słowach - wielkość Boga"2.

\subsection{Bohaterowie historii zbawienia bliscy jako postaci literackie w kunsztownie napisanych dziełach literackich innych niż kroniki}

Literackie postaci Biblii mają $\mathrm{w}$ sobie wielki potencjał realizmu (historii) i kunsztu literackiego, dzięki któremu potrafią silnie oddziaływać na czytelnika. Są one mocno zakorzenione w historii Izraela czy w dziejach życia i nauczania Jezusa z Nazaretu. Narracyjne księgi Pisma Świętego nie są fikcjami literackimi, na które nałożono elementy historii, lecz odwrotnie - są dziełami literackimi przekazującymi historię pod postacią opowiadań i wiarygodnych świadectw. Autorzy tych ksiąg posłużyli się technikami opowiadania typowymi dla fikcji literackiej (np. intreccio, czy dialogi oparte w swej istocie na ustnej tradycji świadectw, ale ostatecznie wyobrażone itp.) $)^{3}$.

Inny jest portret postaci napisany przez historyka (metoda historyczno-krytyczną) niż portret naszkicowany przez pisarza biblijnego (np. ewangelistę). Jednak nie stoją one w opozycji do siebie, nie są ze sobą sprzeczne. Jak podkreśla M.W.G. Stibbe w odniesieniu do Ewangelii według św. Jana: „Jest ona historią napisaną w poetycki sposób. Jest ponownym, kreatywnym zapisem tradycji historycznej, w którym konkretna rzeczywistość (prawda) życia Jezusa nie została w żaden sposób zniszczona czy pomniejszona"4.

Prawdziwa nowość na płaszczyźnie hermeneutycznej, związana $z$ analizą narratywną w odniesieniu do postaci biblijnych, polega na tym, że dowartościowuje się w niej neoarystotelesowski model interpretacji, według którego więcej prawdy zawiera poezja (dzieło literackie) niż historia (kronika), a to $\mathrm{z}$ racji na jej uniwersalizm. Dzieło literackie wprowadza czytelnika w historię,

2 E. Auerbach, Mimesis. Il realismo nella lettura occidentale, t. II, s. 21.

3 Niezwykle trafnie tę relację między twórczością literacką a prawdą historyczną świadectw i tradycji biblijnych ujął R. Alter, pisząc: „Autorzy biblijni są zawsze świadomi tego, że winni opowiadać wydarzenie, które objawia obwiązującą prawdę, która odsłania się w dziełach dokonanych przez Boga w historii („la verità imperativa delle opere di Dio nella storia”), ale także nadzieje i braki Izraela. Uwaga, z jaką winniśmy odczytywać strategie literackie, za pomocą których ta prawda jest wyrażana, może nam pomóc lepiej zrozumieć, może pozwolić nam dostrzec nawet najmniejsze elementy złożonego planu (Bożego) zarysowanego w historii świętej” („del complesso disegno tracciato nella storia sacra biblica”). R. Alter, L'arte, s. 63n.

4 M.W.G. Stibbe, John as Storyteller, s. 75. 
zmniejsza czy wręcz niweluje dystans. Analiza ściśle historyczna (kronika) natomiast oddala go od przypominanej (badanej) historii, stwarza dystans ${ }^{5}$.

W wyjątkowy sposób ten realizm historyczno-literacki jest wzmocniony przez fakt, że teksty biblijne przekazują objawienie Boże, są natchnione. Ukazywane w nich postaci literackie urastają do rangi archetypów wiary (por. Hbr 11,1-12,2; Syr 44,1-50,24). Ale oprócz wiary niezwykle mocno podkreślana jest w narracjach biblijnych cierpliwość i wytrwałość wśród cierpień (por. Hiob; i refleksje w Jk 5,7-8.10-11). Niezwykle ważna w działaniu i życiu postaci literackich Biblii, $w$ ich rozwoju jest modlitwa, często poddawana próbom (por. modlitwa Eliasza; odniesienie do niej w Jk 5,16-17).

$\mathrm{Z}$ uwagi na wymienione wyżej cechy postaci literackie występujące w narracyjnych księgach Biblii żyją w tekście natchnionym i poprzez tekst natchniony tak, jak on się kształtuje w swoim układzie przestrzenno-czasowym (zdanie po zdaniu, początek - koniec dzieła literackiego). W nim pojawiają się, rozwijają, znikają i znów się pojawiają, by ostatecznie zakończyć swe przygody w tekście. Ale kontynuują swe dzieje, odczytane i przemyślane, w umyśle i życiu czytelnika. Wiele postaci biblijnych to "archetypy” - ponadczasowe modele postaw względem Boga i ludzi. Re-kreować te postaci historii zbawienia utrwalone w narracjach biblijnych to inaczej mówiąc uczynić je w pełni żywymi we własnej świadomości jako czytelnika, uczynić obecnymi w czasoprzestrzeni własnego życia w teraźniejszości: aby prowadzić z nimi dialog w celu głębszego zrozumienia, upodobnienia, czy odwrotnie - aby były przestrogą, napomnieniem czy oskarżeniem.

\section{Re-kreacja postaci poprzez analizę tekstu - najważniejsze procedury}

Postać literacka nie jest stuprocentowym, idealnym uobecnieniem jakiejś osoby realnie istniejącej, jako jej sobowtór czy klon. Wiele postaci może odzwierciedlać jedynie kogoś istniejącego w wyobraźni autora. W narracjach postaci istnieją w formie słownej („pod postacią słów”) - istnieją werbalnie: pojawiają

5 Z uwagi na ten bezpośredni „kontakt” postaci z czytelnikiem w narracjach biblijnych dominują dialogi, w których wyrażają one w pierwszej osobie swoje myśli, uczucia, postanowienia, marzenia, obawy. $\mathrm{Z}$ tego samego też powodu autorzy natchnieni bardzo często posługują się formą monologu, w którym postać odsłania swój wewnętrzny świat. W narracjach biblijnych niemal na każdym kroku możemy dostrzegać tendencję do charakteryzowania (stylizowania) postaci w pierwszym rzędzie za pomocą dialogów niż czynów. Por. R. Alter, Larte, s. 84-111. 
się, rozwijają, osiągają ostateczny kształt w słowach i poprzez słowa opowiadania, w tekście i poprzez tekst.

Stąd też chcąc poznać postać opowiadania, czytelnik winien uważnie badać tekst i odkrywać w nim te wszystkie elementy, za pomocą których autor ją kształtuje, a następnie złożyć je w organiczną całość.

Roz-poznawanie czy re-kreacja postaci literackiej to niezwykle twórcze zadanie, jakie autor opowiadania stawia przed czytelnikiem. Ale wypełniając je, czytelnik „ożywia” postać literacką. Wypełniając to zadanie od-tworzenia postaci, czytelnik musi strzec się przed dwoma pokusami: rzekomo obiektywnego formalizmu (polegającego na kurczowym trzymaniu się litery tekstu) i subiektywnego konstruktywizmu (fantazjowania, polegającego na zastępowaniu danych tekstowych własnymi dopowiedzeniami, rozwinięciami, uwagami, ocenami).

Postaci literackie „żyją” dzięki równoczesnemu współdziałaniu tekstu (autora) i czytelnika. Autor w opowiadanej przez siebie historii stworzył je przy pomocy różnorodnych środków literackich. Czytelnik natomiast winien jak najpilniej odkryć i zinterpretować wszystkie te elementy narracji, poprzez które autor kreuje każdą postać, aby poszczególne postaci zaczęły „żyć” w pełni przed nim (w jego świadomości jak na ekranie kinowym), a równocześnie w nim (jako postać interioryzowana, którą naśladuje lub z którą się zmaga, a nawet walczy).

W procesie rekonstrukcji postaci literackiej czytelnik może i powinien posłużyć się także wszelkimi danymi kontekstowymi: intratekstualnymi, intertekstualnymi (przy postaciach NT odniesienie do ST), historyczno-kulturowymi.

Dokonywany przez czytelnika proces rekonstrukcji czy re-kreacji postaci literackiej obejmuje kilka działań. Każde z nich pozwala mu odkryć jakiś ważny element lub rys re-kreowanej postaci.

Dopiero wtedy, gdy postać zostanie przez czytelnika „od-tworzona” albo „ożywiona”, może we właściwy sobie sposób na niego oddziaływać. Sposób tego oddziaływania zależy od autora, a dokładniej mówiąc od napisanego przezeń tekstu, czyli od sposobu, w jaki stworzył postać „zakutą” w słowach. Zobaczmy zasadnicze etapy procesu re-kreowania postaci literackiej.

Podsumowując, tylko współdziałanie autora, tekstu i czytelnika pozwala odkryć sens (prawdę) objawiający się w postaci literackiej, poruszającej się wewnątrz określonej fabuły (intreccio). 


\subsection{Postać wewnątrz fabuły: czyli co postać robi i co się z nią dzieje?}

Zadaniem czytelnika, który chce analizować postać literacką, jest jej od-tworzenie w zwartej prezentacji. Autor stworzył jej portret i dynamiczne dzieje wewnątrz dzieła literackiego (tekstu), posługując się narzędziami właściwymi dla siebie jako „wszechmocnego" narratora.

Re-kreowanie postaci literackiej przez czytelnika (egzegetę) zaczyna się od wyodrębnienia jej własnej historii i wyraźnego określenia wszystkich jej działań, doznań, przeżyć, wydarzeń, w których uczestniczyła. Postać bowiem objawia się w czynach, a czyny mają zasadniczy wpływ na jej tożsamość, a co za tym idzie na to, jak autor może przez nią oddziaływać na czytelnika: co może mu komunikować, do czego wzywać bądź przed jakimi działaniami przestrzegać.

Ogromnie ważną rzeczą jest także określenie wpływu czynów lub zachowań badanej postaci na rozwój całej akcji będącej przedmiotem opowiadania. $\mathrm{Na}$ ile jej działania i zachowania są typowe tylko i wyłącznie dla niej, czyli na ile jest inna i niezależny od innych postaci, ich działań i zachowań. Postać bowiem w pierwszym rzędzie zależy od rozwoju wątku akcji, a rozwój wątku akcji zależy od postaci.

Każde opowiadanie ma charakterystyczne miejsca, czasy, środowiska, które dla prezentowanej historii są mało ważne, ważniejsze lub zgoła najważniejsze. Nie bez znaczenia dla procesu re-kreowania postaci jest zatem i to, w jakich momentach fabuły postać ta się pojawia, w jakich miejscach fabuły (kiedy i gdzie) podejmuje właściwe sobie działania, a gdzie i kiedy one się kończą.

Kolejne pytanie w procedurze re-kreacji postaci winno dotyczyć tego, jakie środowiska lub zwyczaje mają wpływ na jej działanie lub zachowanie wewnątrz fabuły. Na ile postać ulega tym wpływom (dobrym czy złym), a na ile jest wobec nich niezależna czy wręcz im się przeciwstawia, zdobywając własną oryginalność (pozytywną czy negatywną).

W analizie postaci literackiej chodzi zatem o to, aby rozpoznać i organicznie zintegrować (połączyć w logiczną całość) działania i zachowania charakterystyczne dla niej, dzięki którym zdobywa w narracji samodzielne istnienie werbalne. Najważniejszą procedurą jest bez wątpienia wydobycie $\mathrm{z}$ fabuły tych działań i słów, dzięki którym badana postać pełni właściwą dla siebie rolę w opowiadanej historii.

Krótko mówiąc, chodzi o pokazanie:

- czy jest postacią podejmującą zawsze jednakowe, proste działania, czy raczej jej aktywność jest różnorodna; jeżeli jest różnorodna, to jest koherentna czy wewnętrznie sprzeczna, pełna napięć, nagłych zwrotów, nieprzewidywalnych posunięć́?; 
- czy jest postacią spełnioną (kompletną), realizującą otrzymane zadanie/powołanie bądź własne wizje i pragnienia do końca, czy nie?;

- czy i na ile jest postacią ważną dla fabuły i dlaczego?;

- jaki jest związek jej czynów z działaniami innych postaci: czy potrafi współdziałać czy raczej zawsze występuje w opozycji do zachowań innych postaci (jakich i dlaczego)?;

- jakie autor przekazuje orędzie czytelnikowi, związane z jej udziałem w wątku narracji i w prezentowanej historii; w jakiej formie je przekazuje: wyjątkowego czynu czy wygłaszanej sentencji?

- kim się staje, jak się rozwija (bądź nie) dzięki właściwemu sobie uczestnictwu $\mathrm{w}$ tak lub inaczej opowiadanej historii.

Dobrą metodą odkrycia tych wszystkich odniesień jest sporządzenie tabeli z czterema rubrykami: 1) sigla; 2) kto mówi; 3) do kogo; 4) co mówi. Mając ją przed oczami, łatwo możemy określić: w którym miejscu fabuły są podejmowane określone działania lub wypowiadane słowa dotyczące działań bądź zachowań postaci - i przez kogo (przez nią samą czy przez innych: przez kogo $w$ relacji do niej).

Badając postać wewnątrz fabuły, czytelnik odkrywa najważniejsze jej działania i związane z nimi słowa, a nawet pojedynczy czyn bądź słowo o przełomowym znaczeniu dla jej aktywności w historii. Od nich zależy jej znaczenie wewnątrz fabuły. Analiza według tej procedury pozwala zobaczyć, kiedy i w jakich okolicznościach postać stała się „ważna” czy wręcz „wielka”, czyli dzięki czemu jej życie ma sens i na czym on w gruncie rzeczy polega. Ułatwiając czytelnikowi poznanie tego, autor biblijny komunikuje mu niezwykle ważną prawdę o człowieku zanurzonym w historii zbawienia - prawdę o tym, że jego aktywne uczestnictwo w niej, wyrażające się w określonych formach i okolicznościach działania, ma sens. Potrafi nawet sugerować - jeżeli życie czytelnika i opowiadana historia są jakoś sobie bliskie pomimo różnicy czasu czy miejsca akcji na czym on w gruncie rzeczy polega bądź może polegać, a jedynie należy się zaangażować, aby go osobiście odkryć.

Należy zdawać sobie sprawę z faktu, że postać w fabule, jakkolwiek w dużej mierze określona przez swoje czyny, nie sprowadza się do poziomu tzw. roli czy funkcji („aktanta”; „uczestnika” utożsamiającego się całkowicie z tym, co robi $-\mathrm{z}$ funkcją $)^{6}$. Nie da się bowiem rozdzielić w postaciach narracji działań

6 Takie utożsamienie proponują zwolennicy strukturalizmu (postać jako podmiot spełniający ściśle określone, niezmiennie te same czynności) i semiologii (postać jako znak określonej siły aktywnej w badanym wątku). Zamiast o "postaci” wolą mówić o "funkcji”, przez którą rozumieją „działanie określonej postaci rozpatrywane z punktu widzenia jego znaczenia dla rozwoju wątku" - jak pisze W. Propp (Morfologia bajki, s. 27), reprezentant 
od myślenia, aktów woli czy wszelkiego rodzaju uczuć, które mają znaczący wpływ na ich działanie ${ }^{7}$.

\subsection{Konsystencja postaci - prostota lub złożoność: niezmienność i doskonałość czy przemiana?}

W narracjach można wyróżnić postaci proste, niemal „jednowymiarowe”, monolityczne, oraz postaci złożone, „wielowymiarowe”, skomplikowane pod względem konsystencji osobowej. Postaci monolityczne, zwane także zamkniętymi, są wyposażone w jakąś jedną, dominującą w każdej sytuacji cechę cha-

szkoły rosyjskich formalistów, który zajmował się strukturami narracyjnymi bajek ludowych. Wylicza najważniejsze funkcje, które postaci w badanych przez niego bajkach podejmują postaci narracji w pewnych konkretnych okolicznościach i one decydują o tym, że są właśnie postacią danego rodzaju. Te działania, formy aktywności, to funkcje: odejście, zakaz, naruszenie zakazu, wywiadywanie się przeciwnika, udzielenie mu informacji o bohaterze, podstęp, wspomaganie lub szkodzenie (lub brak kogoś albo czegoś), pośredniczenie, rozpoczynające się przeciwdziałanie, wyprawa, pierwsza funkcja donatora, reakcja bohatera, przekazywanie środka magicznego, przemieszczenie przestrzenne między dwoma królestwami, walka, naznaczenie bohatera znamieniem, zwycięstwo, likwidacja wcześniej zaistniałego braku czegoś, powrót bohatera, prześladowanie bohatera, ocalenie bohatera od pościgu, nierozpoznane przybycie, roszczenia fałszywego bohatera, trudne zadanie, wykonanie trudnego zadania, rozpoznanie, zdemaskowanie, transfiguracja, ukaranie, wesele Jak zauważa W. Propp, nie wszystkie te funkcje są jednakowo niezbędne, zdarzają się bajki bez niektórych, zdarzają się pewne różnice w kolejności funkcji, ale niektóre, najważniejsze funkcje, występują zawsze. W bajkach badanych przez Proppa działa kilka typów postaci: bohater, przeciwnik, donator (osoba poddająca bohatera próbie), pomocnik, królewna lub jej ojciec, osoba wysyłająca, fałszywy bohater Są to określenia umowne, na podstawie najczęściej występujących przypadków. W jakiejś konkretnej bajce może to być np. ktoś inny niż królewna czy jej ojciec, ale pełni tę samą funkcję. Zob. W. Propp, Morfologia bajki magicznej). Por. także analizę postaci od strony semiologii P. Hamon, Pour un statut sémiologique du personage, s. 115-180.

7 Krytykę formalizmu w analizie postaci w pismach W. Proppa i innych reprezentantów tego nurtu (a także semiologii) przeprowadza H. Bredin, The Displacement of Character In Narrative Theory, s. 295-296; por. także P. Hamon, który nawet jako reprezentant semiologii stwierdza jednak: „Le personnage est défini:1) Par son mode de relation avec les fonctions qu'il prend en charge; 2) Par son intégration particulère (isomorphisme, démultiplication, syncrétisme); 3) Par son mode de relation avec d’autres actants; 4) Par sa relation à une série de modalités (vouloir, savoir, pouvoir) et leur ordre d’acquisition; 5) Par sa distribution au sein d'un récit; 6) Par le faisceau de qualifications et des rôles dont il est le support (spécialisation etc.) - P. Hamon, Pour un statut sémiologique du personage, s. 117. 
rakteru lub sposób działania. Ich zachowanie w każdej sytuacji łatwo można przewidzieć ${ }^{8}$.

Postaci złożone, zwane także "otwartymi”, posiadają wiele cech, które w różnych okolicznościach życiowych mogą dochodzić u nich do głosu i decydować o ich działaniu. Nie sposób przewidzieć, co taka postać w danej sytuacji zrobi, jak się zachowa, co powie. W każdej sytuacji jest ona „otwarta” na wiele możliwości działania. Często są to działania przeciwstawne sobie, prowadzące do konfliktu wewnętrznego, frustracji, rozbicia, a nawet załamania (bądź odwrotnie: ze stanu przygnębienia lub zagrożenia prowadzą postać $\mathrm{w}$ stan radości i pokoju). Jednak pomimo swej nieprzewidywalności i niejednokrotnie przeciwstawności w działaniu, postać „otwarta” ma w sobie coś, co gwarantuje, że jest spójna, koherentna - inaczej nie byłaby przekonująca. Narrator przedstawia ją w różnorodnych sytuacjach, ukazuje jej wahania lub zestawia takie jej działania, które są sobie przeciwstawne, a nawet wykluczające się ${ }^{9}$. Czytelnik dosyć łatwo odkrywa w nich różne aspekty swoich postaw i działań. Postać „otwarta” szybko staje się mu bliska, jakby należała do jego rodziny, a nawet tak realna jak przyjaciel bądź nieprzyjaciel, z jakim ma do czynienia niemal każdego dnia. Równocześnie w postaci „otwartej” czytelnik odkrywa coś, co przekracza jego dotychczasowy, tradycyjny bądź w miarę utrwalony sposób myślenia i działania. Ma ona także w sobie coś tajemniczego, niedającego się do końca uchwycić i wypowiedzieć. To dzięki temu jest bardzo podobna do osób realnie istniejących w życiu czytelnika i do niego samego ${ }^{10}$.

W Biblii postać „otwarta” to najczęściej bohater pełen wewnętrznych sprzeczności, napięć, a nawet przeżywający wewnętrzną walkę, ścieranie się dwóch czy więcej sposobów myślenia i działania. Dlatego w księgach Pisma Świętego tak wiele miejsca zajmują dialogi: między postaciami, czy postaci z samą sobą. Jak pisze R. Alter,

każda postać ludzka musi mieć wolność, aby zmagać się słowami i czynami ze swoim losem. A to oznacza, że pisarz musi pozwolić każdej postaci ujawnić lub wręcz objawić siebie samego lub siebie samą poprzez dialog, ale także poprzez czyny. [...]. Narrator hebrajski nie wtrąca się otwarcie w dzieje osoby, którą przedstawia, tak jak Bóg tworzy w każdej osobowości ludzkiej pełen niepokoju splot intencji, emocji i kalkulacji wyrażających się w sieci dających się zrozumieć wypowiedzi

8 Jako pierwszy tego rodzaju rozróżnienie postaci w narracjach zaproponował E.M. Forster, Aspetti del romanzo; por. także S. Chatman, Storia e discorso, s. 136.

9 Por. S. Chatman, Storia e discorso, s. 137.

10 Por. P. Ricoeur, Soi-même comme un autre, s. 147-148. 
językowych, którą indywidualna postać sama musi rozwikłać podczas swej indywidualnej egzystencji ${ }^{11}$.

Doskonałym przykładem tego rodzaju postaci są: Mojżesz (por. Wj 3,1-4,17), Saul (bohater w 1 Sm 11; antybohater w 1 Sm 13-14; bohater tragiczny w $1 \mathrm{Sm} \mathrm{15}$; jako antagonista i przeciwieństwo nowego bohatera Dawida w 1 Sm 17), Eliasz (nieugięty i odważny bohater w $1 \mathrm{Krl}$ 18; pełen lęku, uciekający przed Jezabel w $1 \mathrm{Krl} 19)^{12}$.

Aby czytelnik mógł łatwiej re-kreować postać literacką pod względem jej konsystencji, jeden z narratologów proponuje potrójny model postaci, którym można się posłużyć:

- postać ukazana od początku opowiadania jako kompletna, co narrator zaznacza przypisując jej już w momencie pojawienia się w fabule jakąś cechę, która w dalszym ciągu wydarzeń jest nieustannie potwierdzana (np. Józef „sprawiedliwy”);

- postać wyłaniająca się jako kompletna w toku akcji. Po początkowym krótkim i ogólnym przedstawieniu, postać z każdym swoim działaniem, wypowiedzianym słowem staje się coraz bardziej żywa, a w pełni określona zostaje dopiero na końcu akcji, jak na przykład Samarytanka czy „umiłowany uczeń” w Ewangelii według św. Jana;

- postać radykalnie przekształcona w toku akcji. Obraz początkowy takiej postaci zmienił się, i to gruntownie, wskutek rozwoju uwarunkowanego upływem czasu, wskutek podejmowanych przez nią działań, spotykanych osób, aktywnego uczestnictwa w nowych wydarzeniach ${ }^{13}$.

W każdym z tych modeli chodzi o uchwycenie „życia wewnętrznego” postaci, czynników sprawiających jej przemianę, zmiany stosunku do innych, rozwoju uczuć, systemu wartości, jej punktów patrzenia na życie (psychologicznych i ideowych) ${ }^{14}$.

\subsection{Specyfika postaci - jej indywidualność albo wyjątkowość}

Każda postać ma takie cechy lub sposoby działania, które są właściwe tylko dla niej. Decydują one o tym, czy i na ile jest ona indywidualnością. Autor objawia je czytelnikowi na różne sposoby:

R. Alter, L'arte, s. 111.

12

Por. ibidem, s. 84-95.

13

Por. M.W.G. Stibbe, John as Storyteller, s. 24-25.

14

Por. R. Scholes - R. Kellog, La natura della narrativa, s. 214-215. 
- sumując lub syntetycznie ujmując działania postaci, opisując jej gesty, postawy, przyzwyczajenia, podając jej imię;

- komentując jej zachowanie ustami innej postaci;

- przytaczając to, co postać mówi;

- dając poznać to, co postać myśli, mówi do siebie w formie monologu wewnętrznego. Te cztery formy prezentacji postaci przyjęło się nazywać mianem showing (autor pozwala czytelnikowi samodzielnie „widzieć” i „słyszeć” postać). Jest to procedura w miarę obiektywna, jakkolwiek wiele także i tu zależy od narratora, sposobu prezentacji jej czynów lub słów.

$\mathrm{Z}$ kolei poprzez wtrącenia, uwagi czynione przez narratora, a dotyczące działania postaci fabuły, jego celów lub motywów kierujących tym działaniem, streszczenia i podsumowania autor/narrator w sposób bezpośredni „mówi” (telling) czytelnikowi coś ważnego na temat konkretnej postaci literackiej.

W prezentacji indywidualności postaci według modelu showing można dostrzec:

- wypowiedzi deskryptywne, opisujące postać, odsłaniające to, kim ona jest;

- wypowiedzi narratywne, ukazujące, jak ona działa.

Każda z tych wypowiedzi, ale zwłaszcza syntetyczne ujęcia działań, imiona, czy opisy postaci, skłaniają czytelnika do wyciągania wniosków, do oceny postaci dosyć mocno sugerowanej przez autora/narratora. Jednak ocena czytelnika nie może być bezkrytyczna, ani tym bardziej całkowicie arbitralna, oderwana od zawartej w tekście oceny autora/narratora. Winna być dokonywana bardzo wnikliwie, krytycznie, ostrożnie, rzetelnie, z zachowaniem maksymalnej wierności względem tekstu, a także z odniesieniem do kultury, w której postać funkcjonuje, do utrwalonych w niej kodów czy modeli. Wielkość narracji w dużej mierze polega na tym, że postać może być oceniana w dwojaki sposób. Wówczas bowiem autor odzwierciedla złożoność czynników, które oddziałują na człowieka oraz niemałą trudność, jaką jednostka ma w rozszyfrowaniu najbardziej głębokich motywów swego działania lub działania innych podmiotów. Taka narracja i tak przedstawiona postać jest niemałym wyzwaniem intelektualnym dla czytelnika. Skłania go bowiem do precyzyjnego określenia tego, o czym tekst milczy, albo pozwala jedynie się domyśleć. Poprawne, czyli zgodne z prawdą odkrycie rzeczywistej specyfiki tak zaprezentowanej postaci to tak jak odczytanie trudnego, skomplikowanego szyfru ${ }^{15}$. Gdy istnieje kilka możliwości „rozszyfrowania” specyfiki danej postaci, należy wybrać tę, która uwzględnia możliwie najwięcej danych zawartych w tekście i kulturze środowiska. Nie można przy tym zapominać, że w narracjach wysokiej klasy postać

15 H. Grosser, Narrativa, s. 253. 
może mieć dwie albo i więcej nakładających się na siebie wyjątkowych specyfik czy „indywidualności” (tzw. polisemia).

W przypadku wypowiedzi innych podmiotów fabuły na temat interesującej czytelnika postaci należy krytycznie rozróżniać, kto mówi, na podstawie czego to mówi, z jakiego punktu widzenia i dlaczego, czyli na ile jest to wypowiedź wiarygodna i pomocna w odkrywaniu specyfiki tej konkretnej postaci. W narracjach biblijnych często Bóg lub Jezus zabiera głos w odniesieniu do sposobu myślenia, mówienia czy działania postaci literackiej. Może to być afirmacja, ostrzeżenie, pochwała - ale możliwa jest także ironia. Należy ją dostrzegać, ale nie wbrew tekstowi, jego gatunkowi czy stosowanej przez autora retoryce $\mathrm{z}$ wieloma pytaniami retorycznymi, kierowanymi przez Boga czy Jezusa do postaci występującej w fabule.

Wyjątkowo ważne w ocenie postaci są jej własne wypowiedzi, odzwierciedlające jej sposób myślenia, motywacje, argumenty, uczucia. Paul Ricoeur proponuje, aby oceniać postać według tego, czy jest wierna względem „danego przez siebie słowa”. Ale w tych jej wypowiedziach równie ważne jest jej stanowisko względem tego, co mówią i jak działają inne postaci, ich punktu widzenia problemu czy punktu widzenia samego narratora. Taka analiza pozwoli wyraźniej dostrzec specyfikę postaci.

Ogromnie ważna w ocenie indywidualności czy wyjątkowości postaci jest analiza jej aktów lingwistycznych („każde mówienie jest działaniem”) ${ }^{16}$. Wśród różnorodnych wypowiedzi postaci da się wyodrębnić:

- akty lokucji (co mówi);

- akty illokucji (co osiąga albo czego dokonuje przez swoje mówienie);

- akty perlokucji (do jakiego działania zamierza skłonić inne postaci swoim mówieniem $)^{17}$.

Najłatwiej odkryć wyjątkowość postaci, gdy autor ustami narratora sam ją czytelnikowi expressis verbis określa. Często także wnika w samą istotę motywacji lub zamiarów, które nią kierują. Autorzy biblijni są w tej materii godni wiary. Często czynią to poprzez wybór takiego imienia, które wiele mówi o postaci, określa główny rys jej duszy (świata wewnętrznego), a równocześnie odpowiadającą mu rolę wewnątrz fabuły. Imię fokalizuje pozostałe, indywidualne cechy postaci. Często ma funkcję proleptyczną - antycypując zasadniczą wymowę narracji. Może być też swego rodzaju mocnym imperatywem skłaniającym postać do ściśle określonych działań. W literaturze starożytnej, także w Biblii imię jest najczęściej „metaforą osoby” (np. Adam, Ewa, Abel, Jezus). Zmiana imienia oznacza zmianę roli życiowej, często także miejsca i stylu ży-

16 Pisał o tym J.L. Austin, How to Do Things with Words.

17 Por. J.P. Sonnet, La parole consacrée. 
cia, mając ogromny wpływ na dalszy kształt fabuły. Imię bowiem ma bogate konotacje społeczne, kulturowe, czy wręcz symboliczne ${ }^{18}$.

Poza tym o indywidualności postaci w Biblii decyduje jej związek ze światem nadprzyrodzonym: nadzwyczajne interwencje Boga w jej dzieje, wizje, wyrocznie, sny objawieniowe, pewność wsparcia ze strony Łaski Bożej bądź Ducha Bożego. Budzą one w czytelniku empatię względem postaci. Równocześnie interwencje Boga w dzieje postaci biblijnych narracji każą czytelnikowi dostrzegać Jego pierwszoplanową rolę, ale także wyznaczają jej tajemniczość, nieprzewidywalność jej losów bądź efektów działania, ukierunkowanie na odpowiedzialność przed Nim i osąd z Jego strony ${ }^{19}$.

\subsection{Postać $w$ relacji do innych podmiotów narracji - świat postaci}

Żadna postać literacka - jak żaden człowiek realnie istniejący - nie żyje w izolacji. Wokół każdej postaci w trakcie rozwoju fabuły tworzy się grono osób, pośród których i dzięki którym żyje, podejmuje takie a nie inne działania. Równocześnie każda postać w bardzo konkretny i właściwy dla siebie sposób oddziałuje na osoby, które żyją wokół niej. Fabuła każdego opowiadania opiera się na tym, że jedna postać $\mathrm{w}$ różny sposób, na różnych poziomach oddziałuje na inne, a to jej oddziaływanie ma jakiś sens, albowiem zmierza do osiągnięcia jakiegoś jednego celu, bądź też uniemożliwia innym jego osiągnięcie. Biorąc pod uwagą możliwe powiązania jednej postaci literackiej z innymi figurami występującymi w opowiadaniu, wyróżnia się następujące relacje: podobieństwa lub niepodobieństwa, paralelizmu lub antytezy; repetycji lub gradacji ${ }^{20}$. Na każdą z tych relacji może nakładać się fakt reprezentowania różnych wartości: przeciwstawne sobie postaci mogą reprezentować dobro i zło, szczęście i nieszczęście, wiarę i brak wiary, miłość i nienawiść.

Biorąc pod uwagę te relacje, czytelnik jest w stanie określić wielkość konkretnej postaci. Wyznacza ją wiele czynników, ale zwłaszcza relacje, jakie istnieją między badaną postacią a innymi podmiotami. Są to głównie wymienione wyżej relacje podobieństwa, integracji lub opozycji, a nawet konfrontacji. Analizując te relacje, postać można określić mianem:

- protagonista, postać nieodzowna w fabule, wyznacza bieg akcji (często naprzeciw niego występuje antagonista);

18 Por. M. Sternberg, The Poetics of Biblical Narrative, s. 328-342.

19 Por. J.L. Ska, „Our Fathers have Told Us”, s. 90-91.

20 Bardziej szczegółową analizę postaci w relacji do innych podmiotów biorących udział w fabule przedstawił H. Grosser, Narrativa, s. 237-286. 
- towarzysz (postać występująca u boku, za plecami), służy do podkreślenia cech postaci czołowych (jak Jozue i Aaron u boku Mojżesza);

- sługa lub obserwator, czyli osoby, których działanie pozostaje w służbie rozwoju fabuły, ale mógłby je spełnić ktokolwiek inny. Często są to świadkowie obserwujący to, co się dzieje;

- tłum, chór, rzesza, czyli postaci, których obecność wewnątrz fabuły ma niewielki albo żaden wpływ na rozwiązanie problemu, o którym mowa w opowiadaniu.

Rzecz jasna, relacje jakiejś postaci literackiej z innymi podmiotami fabuły - jak wspomniano - albo wpisują się w nurt ich współdziałania albo konfrontacji. Wszystko zależy od jej wolności, a ostatecznie od punktu, z jakiego $\mathrm{w}$ danym momencie patrzy na problem, zarysowany na początku fabuły. Tekst zazwyczaj informuje czytelnika, jaki jest generalny (i szczegółowy - w danym momencie fabuły) punkt widzenia narratora (autora dzieła), sugerowany także czytelnikowi. Wielkość postaci zależy od tego, na ile przyczynia się do rozwiązania problemu, postrzeganego z punktu widzenia narratora, i w jakim stopniu współdziała $\mathrm{z}$ innymi lub przezwycięża stawiane mu przez innych przeszkody.

Postaci literackie - oprócz zarysowanych wyżej postaw - mogą wchodzić $\mathrm{w}$ relacje $\mathrm{z}$ innymi według dwóch schematów. Pierwszy to schemat słabych relacji między postaciami opowiadania, gdy wszystkie one pozostają w jakiejś relacji tylko do protagonisty, a nie nawiązują żadnych więzi między sobą. W narracjach biblijnych protagonistą jest Bóg lub Chrystus. Ludzie natomiast najczęściej postrzegani są w pierwszym rządzie pod względem ich wiary, która pozwala im współdziałać z protagonistą, a jej brak stawia ich $\mathrm{w}$ rzędzie antagonistów.

Drugi to schemat relacji mocnych, gdy wzajemne oddziaływania także między postaciami innymi niż protagonista są różnorodne i silne. Często w literaturze zdarza się, że relacje między postaciami urastają do rangi fenomenu zwanego „dublerem literackim”. Może on mieć charakter artystyczny, gdy chodzi o ukazanie lub wydobycie jakiejś ważnej prawdy poprzez rozdzielenie podmiotów i agentów działających na dwa, przeciwstawne sobie obozy. Może on też mieć charakter psychologiczny, gdy dla lepszego opisania tożsamości osobowej postaci autor stawia obok niej jej alter ego, które jest jej przeciwieństwem lub dopełnieniem. 


\section{Postać w relacji do narratora: zadanie postaci w stosunku do czytelnika}

$\mathrm{Na}$ tym etapie chodzi o ustalenie, na ile re-kreowana przez czytelnika postać realizuje program, zamierzony przez narratora. Innymi słowy, należy precyzyjnie ustalić, jaki związek zachodzi między postacią, rozwojem fabuły, a programem albo lepiej celem czy strategią opowiadania, jaką objął narrator. Ale precyzyjne określenie programu lub celu zamierzonego przez autora/narratora nie jest sprawą prostą, chyba że jest on expressis verbis sformułowany. Najbardziej podstawową formą, w której autor/narrator prezentuje swój cel (a także strategię narracyjną) jest tzw. rama literacka, czyli ten tekst, w którym autor łączy świat narracji ze światem rzeczywistym, historycznym. Najczęściej czyni to we wprowadzeniu i zakończeniu (w prologu i epilogu), jakkolwiek nie tylko w tych częściach dzieła ${ }^{21}$.

Gdy takiej ramy literackiej nie ma, wówczas należy dokonać całego szeregu rozróżnień (między autorem/lektorem rzeczywistym a idealnym, czyli takim, jakiego autor chce ukształtować obranymi przez siebie środkami w formie modelowych postaci bądź samym przebiegiem wątku akcji i dokonującą się w nim transformacją postaci). Trzeba pamiętać, że nie tylko protagonista, ale wszystkie postaci w różny sposób są przez narratora włączone w realizację celu, który sobie postawił, pisząc swoją narrację. Na przykład w Ewangelii według św. Jana niemal w każdej perykopie, w której występuje konkretna postać literacka, czytelnik jest zaproszony do konfrontacji swej wiary/niewiary w Jezusa jako Mesjasza i Syna Bożego (por. J 20,30-31) z jej wiarą lub niewiarą. W ten sposób swoją strategię narracyjną ewangelista realizuje nie tylko w całym dziele jako

21 Szczegółowo rolę takiej ramy literackiej jako prezentacji strategii i celu autora/narratora analizuje B. Uspensky, A Poetics of Composition, s. 147; por. także J. Culler, Sulla decostruzione, s. 175-182; z kolei J.N. Aletti (L’arte di raccontare Gesu Cristo, s. 177-198) analizuje treść takiej ramy literackiej w Łk 1,4 i 24, 16.31. Mając do dyspozycji wiarygodne świadectwa zawarte w Ewangelii (por. 1,4), czytelnik jest zaproszony przez ewangelistę do utożsamienia się z uczniami idącymi do Emaus, a zwłaszcza do tego, aby wraz z nimi przejść od brakującego do dokonanego rozpoznania Jezusa (24,16.31); w Ewangelii według św. Jana rolę ramy literackiej oprócz hymnu o Logosie $(1,1-18)$ pełnią teksty pisane prozą $(1,19-$ $-2,12$ - gdzie występuje wiele elementów typowych dla ramy literackiej; 19,$35 ; 20,30-31$ i 21,24). Szczegółową analizę tej ramy literackiej przeprowadza R. Vignolo, Personaggi del Quarto Vangelo, s. 47-50. 
takim, ale także w poszczególnych jego częściach (np. rozdziałach), stanowiących mniejsze, ale równie zwarte jednostki literackie ${ }^{22}$.

W narracjach biblijnych, w których występuje wszystkowiedzący narrator zewnętrzny w stosunku do uczestników fabuły, komunikacja (dialog) między nim (i autorem) a czytelnikiem jest niezwykle intensywny. Zwłaszcza w Ewangeliach można obserwować wysiłek narratora, aby przekonać czytelnika do podjęcia lub zaniechania określonych działań. Czytelnik jest $\mathrm{w}$ nich widzem uprzywilejowanym, gościem narratora zewnętrznego i bezstronnego, „wszystkowiedzącego" i ma szansę kontemplować postaci prezentowane w narracji. Postaci te są wzywane zazwyczaj przez Jezusa do podjęcia jakiegoś działania lub do zaufania (wiary) Mu. Czytelnik może je widzieć z bliska, jak podejmują te działania, wierzą, czy też nie potrafią ich podjąć czy zdobyć się na zaufanie wymagane przez Jezusa. Tym samym mają one wielką siłę oddziaływania na postawę czytelnika. Ale pozostaje już jego tajemnicą, na ile autorowi/narratorowi udało się osiągnąć założony cel w zakresie oczekiwanej postawy względem Jezusa Chrystusa. To zależy od tego, jak czytelnik prowadzony przez narratora (znającego prawdę) ocenił daną postać i jej odniesienie do Jezusa. Ta ocena to najważniejszy element odpowiedzi czytelnika, oczekiwanej przez autora/narratora $^{23}$.

W wielu narracjach biblijnych postaci literackie w swoim oddziaływaniu na czytelnika pełną rolę modeli albo figur paradygmatycznych, a więc takich, które czytelnik winien naśladować. W Ewangeliach są to najczęściej modele lub wzorce wiary chrystologicznej, poprzez które ewangeliści w różny sposób stosują tzw. „perswazję chrystologiczną" ${ }^{4}$, czyli przekonują czytelników każdego pokolenia do wiary w Jezusa jako Chrystusa i Syna Bożego.

\section{Zakończenie}

Podsumowując, należy stwierdzić, że każdy czytelnik znajduje się w sferze oddziaływania autora/narratora i tekstu. Jedną z ważniejszych form tego oddziaływania są postaci literackie. Wnikliwe, wszechstronne i wyczerpujące re-

22 Na tę niezwykle ważną cechę narracji Janowej zwrócił uwagę R.A. Culpepper, Anatomy of the Fourth Gospel, s. 89; szczegółową analizę wielu perykop J pod tym kątem przeprowadził V. Mannucci, Giovanni. Il Vangelo narrante, s. 86-185.

23 O czytelniku czwartej Ewangelii i jego odpowiedzi na postawy postaci prezentowanych w fabule zob. R.A. Culpepper, Anatomy, s. 203-228; por. także S. van Tilborg, The gospel of John: communicative processes in a narrative, s. 19-32.

24 Tego trafnego określenia użył M.W.G. Stibbe, John as Storyteller, s. 22. 
-kreowanie postaci opowiadania sprawia, że w pewnym momencie czytelnik odkrywa w swej świadomości jej obecność; zaczyna być ona postacią żywą i prowadzącą z nim intensywny dialog, oddziałującą na jego zachowanie, sposób myślenia i działania. W celu oddziaływaniu na czytelnika przez postać literacką autor/narrator ma do wykorzystania kilka modeli: postać kluczową dla przebiegu wątku narracji; postać przemienioną $\mathrm{w}$ toku fabuły, postać mającą wyjątkową specyfikę czy wreszcie postać silnie oddziałującą na inne postaci narracji jako protagonista lub antagonista.

Wielkie postaci literackie, stworzone przez autorów piszących $\mathrm{z}$ natchnieniem, a w szczególności przez autorów tworzących pod natchnieniem Ducha Bożego, spełniają cel (realizują strategię narracyjną), który postawił sobie i im autor/narrator: kształtują idealnego czytelnika nie tylko w pierwszym pokoleniu adresatów dzieła literackiego, ale przez wieki, i to pomimo zmieniających się okoliczności, uwarunkowań kulturowych czy środowiska ich życia. Czytelnik natomiast, otwierając się na oddziaływanie postaci literackiej, ma szansę odnieść podwójną korzyść z aktu lektury: po pierwsze, może głębiej wejść w świat opowiadania, aby lepiej zrozumieć złożoność prezentowanego problemu egzystencjalnego (najczęściej ponadczasowego) i całego splotu działań potrzebnych do jego rozwiązania; po drugie, może lepiej zrozumieć siebie, sens swego życia, podejmowanych zmagań, doświadczanych przeżyć bądź lepiej poznać własne szczęście, jakie płynie z unikania zagrożeń i czynników destrukcyjnie ujawniających się w postaciach negatywnych, złych moralnie i duchowo.

\section{Bibliografia}

Aletti J-N., Larte di raccontare Gesu Cristo. La scrittura narrativa del vangelo di Luca, Brescia 1999.

Alter R., L'arte Della narratica biblica, Querniana, Brescia 1990.

Auerbach E., Mimesis. Il realismo nella lettura occidentale, t. II, Torino 1964.

Austin J.L., How to Do Things with Words, Oxford 1962.

Bar Efrat S., Narrative Art in the Bible, (JSSOT SS 70), Almond Press Sheffield 1989, s. 47-92.

Bredin H., The Displacement of Character In Narrative Theory, British Journal of Aesthetics 1982, s. 295-296.

Chatman S., Storia e discorso. La struttura narrativa nel romanzo e nel film, Parma 1981.

Culler J., Sulla decostruzione, Milano 1988.

Culpepper R.A., Anatomy of the Fourth Gospel, Filadelfia 1983.

Grosser H., Narrativa, Milano 1986.

Forster E.M., Aspetti del romanzo, Milano 1968 . 
Hamon P., Pour un statut sémiologique du personage, w: R. Barthes i inni (red.), Poétique du recit, Paris 1977, s. 115-180.

Mannucci V., Giovanni. Il Vangelo narrante. Introduzione allarte narrativa deł Quarto Vangelo, Bologna 1983.

Propp W., Morfologia bajki, przeł. Wiesława Wojtyga-Zagórska, Warszawa 1976.

Propp W., Morfologia bajki magicznej, przeł. Paweł Rojek, Kraków 2011.

Ricoeur P., Soi-même comme un autre, Paris 1990.

Scholes R. - Kellog R., La natura della narrativa, (Saggi 154), Bologna 1970.

Ska J.L., „Our Fathers have Told Us”. Introduction to the Analysis of Hebrew Narratives, (Subsidia Biblica 13), Roma, PIB, 1990, s. 83-94.

Sonnet J.P., La parole consacrée. Théorie des actes de langage, linguistique de l'énonciaction et parole de la foi, Louvain-La-Neuve 1984.

Sternberg M., The Poetics of Biblical Narrative. Ideological Literature and the Drama of Reading, Ind. Un. Press, Bloomington 1987, s. 475-481.

Stibbe M.W.G., John as Storyteller. Narrative Criticism and fourth Gospel, Cambridge 1992 (SNTS MS 73).

Tilborg S. van, The gospel of John: communicative processes in a narrative, Neotestamentica 23 (1989), s. 19-32.

Vignolo R., Personaggi del Quarto Vangelo. Figure della fede in San Giovanni, Milano 1998.

Witczyk H., Czytelnik jako wspótkreator postaci, w: Język Biblii. Od stuchania do rozumienia (Studia Biblica 11), Kielce 2005, s. 70-89.

Uspensky B., A Poetics of Composition. The Structure of teh Artistic Text abd Typology of a Compositional Form, Berkeley-Los Angeles 1973. 